\title{
Prevalence and distribution of feet lesions in dairy cows raised in the freestall
}

\section{Prevalência e distribuição de lesões podais em vacas leiteiras criadas em free stall}

\author{
Rafael Costa Ebling ${ }^{1 *}$; Amanda Krummenauer ${ }^{2}$; Gustavo Machado ${ }^{3}$; \\ Diego Zeni ${ }^{4}$; Luis Paulo Carazzo ${ }^{5}$; Marta Lizandra do Rêgo Leal ${ }^{6}$
}

\begin{abstract}
Foot lesions are one of the main causes of productivity losses in the dairy industry. In this study, we aimed to estimate the prevalence of claudication and distribution of hoof lesions by associating them with preventive hoof trimming, as well as list the main causes of involuntary discarding and the main health problems reported in dairy farms. The study included 10 farms distributed in 7 municipalities of Rio Grande do Sul state. The body condition score (BCS) and locomotion score (LS) of the cows were assessed. Hoof examination, lesion classification, and hoof trimming of the animals were performed. Of the 492 animals, $38.4 \%$ presented lameness and $36 \%$ had foot lesions, $81.4 \%$ of which were observed in the pelvic limbs and $19.6 \%$ in the thoracic limbs. Of the lesions in the limbs, $47.1 \%$ were of infectious origin and $52.9 \%$ were noninfectious. The main lesions were sole ulcers $(31.6 \%)$, digital dermatitis $(30.3 \%)$, thin soles $(12 \%)$, and interdigital dermatitis $(11.2 \%)$. Cows aged 4 to 6 years had a higher number of lesions and a higher LS. Preventive hoof trimming reduced the chances of lameness by $55 \%$ as the locomotive system was the main sanitary problem and the first reason for involuntary disposal of the farms. The results show that dairy cows raised in a free stall system have a high prevalence of claudication and foot diseases. These data should be taken into account when altering the livestock management of these animals in order to reduce significant economic losses in the herd.
\end{abstract}

Key words: Bovine. Foot. Preventive hoof trimming. Lameness.

\section{Resumo}

As lesões podais são uma das principais causas de perdas de produtividade na indústria leiteira. Neste estudo, tivemos como objetivo estimar a prevalência de claudicação e distribuição de lesões de casco associando-as com a realização de casqueamento preventivo, assim como elencar as principais causas de descarte involuntário e de principais problemas sanitários relatados nas propriedades. Foram incluídas no estudo 10 propriedades, distribuídas em 7 municípios do Rio Grande do Sul. As vacas foram examinadas quanto ao seu escore de condição corporal (ECC) e escore de locomoção (EL). Foram realizados os

\footnotetext{
1 Pesquisador, Universidade Federal de Santa Maria, UFSM, Santa Maria, RS, Brasil. E-mail: rafaelcostaebling@gmail.com

2 Discente, UFSM, Santa Maria, RS, Brasil. E-mail: amandakrummenauer@gmail.com

3 Department of Population Health and Pathobiology, North Carolina State University, North Carolina, USA. E-mail: gustavoetal@ gmail.com

4 Prof., Instituto Federal Farroupilha, IFF, São Vicente do Sul, RS, Brasil. E-mail: diego.zeni@iffarroupilha.edu.br

5 Pesquisador, Universidade Anhanguera, UNIDERP, Campo Grande, MT, Brasil. E-mail: ortocasq@hotmail.com

6 Prof $^{\mathrm{a}}$, UFSM, Santa Maria, RS, Brasil. E-mail: martalizandra@gmail.com

* Author for correspondence
} 
exames de casco, a classificação das lesões e o casqueamento dos animais. Dos 492 animais, 38,4\% apresentaram claudicação e $36 \%$ possuíam lesões podais, sendo $81,4 \%$ delas observadas nos membros pélvicos e $19,6 \%$ nos membros torácicos. Das lesões nos membros, $47,1 \%$ foram de origem infecciosa e $52,9 \%$ não infecciosa. As principais lesões diagnosticadas foram úlcera de sola $(31,6 \%)$, dermatite digital (30,3\%), sola delgada (12\%) e dermatite interdigital (11,2\%). As vacas com idade entre $4 \mathrm{e}$ 6 anos apresentaram maior concentração de lesões e maior grau de EL. O casqueamento preventivo reduziu em $55 \%$ as chances de claudicação, assim como o sistema locomotor foi o principal problema sanitário e primeiro motivo de descarte involuntário das propriedades. Os resultados obtidos revelam que vacas leiteiras criadas em sistema free stall apresentam uma alta prevalência de claudicação e de afecções podais. Esses dados devem ser levados em consideração quando da alteração do manejo de criação destes animais, visando a reduzir as expressivas perdas econômicas no rebanho.

Palavras-chave: Bovinos. Casco. Claudicação. Casqueamento preventivo.

\section{Introduction}

The intensification of milk production has led to an increased risk of lameness (HUXLEY, 2012), which is currently considered one of the most important welfare, health, and productivity problems affecting dairy cattle worldwide. Consequently, milk production, reproductive performance, and longevity of dairy cattle decrease, compromising the economic activity of dairy farms. The decreased production may reach $360 \mathrm{~kg}$ of milk per lactation (GREEN et al., 2014).

The causes of lameness in dairy cattle are multifactorial and associated, most of the time, to diet mistakes, deficient management of dairy facilities, and localized infectious processes (LEAN et al., 2013). Studies have pointed out that the type of floor used in certain housing systems (TELEZHENKO; BERGSTEN, 2005), bedding type and low cleaning frequency, paths to access pasture, lack of footbathing (CHAPINAL et al., 2013), and small size of housing facilities (DIPPEL et al., 2009) are factors that may contribute to increased lameness in free-stall dairy cattle.

Using a locomotion scoring system, Von Keyserlingk et al. (2012) assessed the prevalence of lameness in free-stall housed herds, in three regions of North America, including British Columbia, Canada (BC; $n=40)$, California $(C A ; n=39)$, and northeast of the USA (NE; $n=40)$. They observed an average prevalence of lameness of $27.9 \%$,
$30.8 \%$, and $54.8 \%$ in $\mathrm{BC}, \mathrm{CA}$, and NE-USA herds, respectively.

Due to increasing concerns related to hoof lesions in dairy cattle, which may result in economic losses and early culling, and due to a lack of research on this important topic in Brazil, the objectives of this study were to estimate lameness prevalence and hoof lesion distribution and relate this information to the use of hoof trimming as a preventive measure as well as list the main risk factors associated with early culling and main hygiene problems reported by farmers.

\section{Materials and Methods}

The experimental protocol was approved by the Ethics Committee on the Use of Animals, at the Federal University of Santa Maria (no. 4224100117), and by the Research Ethics Committee at the same institution (no. 63958817.3.0000.5346). This study was conducted in rural dairy farms located in the Rio Grande do Sul state. The selection of farms depended on the farmer's availability to participate and all farmers were consulted beforehand regarding their participation in the study and signed an informed consent form.

From 10 April to 02 June 2017, 10 free-stall dairy farms were visited, which were located at the following municipalities: Estrela (E1 and E2), Nova Bassano (NB1, NB2, and NB3), Seberi (S1), Nicolau Vergueiro (NV1), Três Passos (TP1), Santo 
Cristo (SC1) and Catuípe (C1). A total of 492 dairy cows were examined, which were distributed by farm as follows: $\mathrm{TP} 1=171 ; \mathrm{NB} 1=105 ; \mathrm{SC} 1=92$; $\mathrm{NV} 1=32 ; \mathrm{C} 1=29 ; \mathrm{S} 1=25 ; \mathrm{E} 1=17 ; \mathrm{NB} 2=8 ; \mathrm{E} 2$ $=7$; and $\mathrm{NB} 3=6$.

The body condition score (BCS) was evaluated individually by two previously trained veterinary professionals when cows were leaving the milking parlor. BCS was conducted via inspection and palpation of the cow's body (ribs, back, withers, and tail head) with the aim of checking muscle mass and subcutaneous adipose tissue, using a pre-established classification scale from 1 to 5 (EDMONDSON et al., 1989); very thin cows received a score of 1 and obese cows received a score of 5 .

The evaluation of locomotion scoring (LS) was conducted by observing a cow standing and then walking, and classifying them on a scale of 1 to 5 (DIRKSEN et al., 1993); a score of 1 was given if the cow's gait showed no alteration whereas a score of 5 was given if the cow showed severe lameness, which was described as excessive time lying down, extreme difficulty in walking, reluctance to bear weight on the affected foot, extremely arched back, and weight loss.

Subsequently, each cow was placed in the right lateral decubitus position, in a hydraulic cattle chute (Herts ${ }^{\circledR}$, Garça/SP - Brazil). They were identified and their age determined according to an examination of the dental arch (DIRKSEN et al., 1993). Following this step, hoof lesions were classified according to whether they had an infectious etiology and their location in the affected limb. The information collected from each cow submitted to examination was primarily analyzed by descripbing frequencies way. Lesions were distributed into two groups according to their cause: infectious digital dermatitis (D), heel erosion (E), interdigital dermatitis (I), and interdigital phlegmon (F); and non-infectious - white line disease (W), sole ulcer (U), sole hemorrhage $(\mathrm{H})$, toe ulcer $(\mathrm{T})$, screw claw (C), horizontal wall fissure $(\mathrm{G})$, vertical wall fissure $(\mathrm{V})$, axial wall fissure $(\mathrm{X})$, interdigital hyperplasia
$(\mathrm{K})$, and thin sole $(\mathrm{Z})$. Lesion classification was conducted according to standard nomenclature used in Brazil (BORGES et al., 2017).

During visits to farms, an interview was conducted with the farmer or farm workers responsible for the farm management, using a non-validated questionnaire containing open and closed-ended questions. The questionnaire included questions addressing the main hygiene problems faced by farmers and the main reasons for early culling of cows. The purpose of the close-ended questions was to determine whether regular hoof trimming of dairy cows was being implemented.

The distribution of lesions per affected limb (absolute numbers and percentages [\%]) was determined, regardless of its frequency per cow. The relative distribution frequency between locomotion scoring and total of cows examined was determined at the farms included in the study. The correlation between locomotion scoring, age, and number of lesions was conducted using Pearson's correlation coefficient. The distribution of lesions on the hindlimbs was determined according to their specific location and the cow's age, grouped according to their cause (infectious or non-infectious), and a ratio of possibilities on the number of lesions per herd was determined using R 3.0 software (R CORE TEAM, 2013).

\section{Results and Discussion}

Among the 492 cows examined in this study, $37.2 \%(n=183)$ presented some level of lameness (LS>1) (Table 1). In the farms where hoof trimming was implemented in all lactating cows (NB1, TP1, $\mathrm{SC} 1$, and NV1), the following percentages of lame cows were observed during the experimental period: $\mathrm{NB} 1=36.3 \%, \mathrm{SC} 1=25 \%, \mathrm{TP} 1=22.2 \%$, and NV1 $=9.4 \%$. Variations in lameness percentages were observed among different farms, perhaps due to the lack of uniformity observed in the cowsheds and farm management. 
In a study conducted in 50 free-stall dairies, in the Paraná state, Brazil, Costa et al. (2017) detected a high prevalence of lameness in herds (21.1\%). Similarly, Monteiro et al. (2018) observed a prevalence of lameness of $16 \%$ among 48 herds in pasture-based dairies at Minas Gerais, Brazil. The data available on lameness prevalence vary considerably; Martins et al. (2002) suggest that if a herd presents more than $15 \%$ of lame cows, then control measures should be implemented to solve the problem. Cruz et al. (2005) reported that lameness prevalence in intensive-farming dairies may vary from 7 to $55 \%$.

Table 1. Relative frequency between locomotion scoring (LS) and total number of cows examined at select farms where all cows were analyzed.

\begin{tabular}{cccccc}
\hline LS & Global No. (\%) & NB1 No. (\%) & NV1 No. (\%) & TP1 No. (\%) & SC1 No. (\%) \\
\hline 1 & $309(62.8)$ & $68(64.8)$ & $29(90.6)$ & $133(77.8)$ & $69(75)$ \\
2 & $144(29.6)$ & $29(27.6)$ & $2(6.3)$ & $31(18.1)$ & $22(23.9)$ \\
3 & $31(6.3)$ & $8(7.6)$ & $1(3.1)$ & $6(3.5)$ & 0 \\
4 & $4(0.8)$ & 0 & 0 & $1(0.6)$ & 0 \\
5 & $4(0.8)$ & 0 & 0 & 0 & $1(1.1)$ \\
Total & $492(100)$ & $105(100)$ & $32(100)$ & $171(100)$ & $92(100)$ \\
LS >1 (\%) & $183(38.4)$ & $37(36.3)$ & $3(9.4)$ & $38(22.2)$ & $23(25)$ \\
\hline
\end{tabular}

LS: locomotion scoring; No.: total number of cows; total number of cows per dairy farm (NB1, NV1, TP1 and SC1).

Lameness prevalence varies considerably among farms, regions, and production systems, which prevents the determination of predisposing factors of foot problems. A lameness prevalence of $25 \%$ was observed in free-stall housed dairy cows in Wisconsin and Minnesota, USA, whereas 34\% and $63 \%$ of lame cows were detected in California and northeastUSA, respectively (VONKEYSERLINGK et al., 2012). Studies conducted in the UK and Germany reported a lameness prevalence in dairy cows of $37 \%$ and $48 \%$, respectively (BARKER et al., 2010). Similar studies in the Netherlands revealed a lameness prevalence of $16 \%$ (AMORY et al., 2006). The above shows that despite differences of lameness prevalence observed among countries, there is a tendency of greater lameness prevalence in intensive systems of dairy production.

According to Cruz et al. (2005), lesion prevalence is directly related to exposure of cows to predisposing factors, which are mainly related to nutrition and environment. High-producing dairy cows generally receive diets rich in carbohydrates, which are easily digested and have low effective fiber content (NICOLETTI, 2004). Consequently, there is an increase in the amount of volatile fatty acids, which exceeds the capacity of the buffering system in the rumen fluid, causing subacute ruminal acidosis syndrome (BRAMLEY et al., 2013). This condition is strictly related to the occurrence of laminitis (BRAMLEY et al., 2013), which is one of the main causes of other foot problems (NICOLETTI, 2004).

The greatest difficulties faced by dairy cattle production are the implementation of efficient hygiene practices that prevent accumulation of organic matter and high humidity levels on the floors, which are factors contributing to the softening of the hoof and interdigital space, making the cow's feet more susceptible to lesions. The type of floor used in free-stalls, generally with abrasive characteristics (SOMERS et al., 2005) increases the wear rate of the sole; new horn forming tissues should be allowed to be produced on the hoof, otherwise, cow performance is affected. Cowsheds varied among 
farms and depended on each farmer's capabilities, but all facilities were designed according to the free-stall system basic characteristics, in which lactating cows are kept in cubicles, with abrasive and harsh floors, a factor that may be related to the high lameness prevalence and foot lesions observed.

The frequency of foot lesions found in cows examined in this study was $36 \%$, and in many cases, more than one lesion was observed per cow, making a total of 465 foot lesions (Table 2). Among them, the most prevalent were sole ulcers $(31.6 \%)$, followed by digital dermatitis $(30.3 \%)$, thin soles $(12 \%)$, interdigital dermatitis $(11.2 \%)$, interdigital phlegmon (4.1\%), screw claws $(3.7 \%)$, toe ulcers (3.4\%), interdigital hyperplasia (1.5\%), heel erosion $(1.5 \%)$, and sole hemorrhage $(0.6 \%)$. Solano et al. (2016) also detected a prevalence of $36 \%$ of lesions in a study conducted at free-stall dairies in Alberta, Canada.

Table 2. Distribution of lesions on the affected limbs (absolute numbers and percentages [\%]), regardless of lesion numbers found per cow. FL: forelimbs; HL: hindlimbs.

\begin{tabular}{lcccccc}
\hline & FL & FL (\%) & HL & HL (\%) & Total & Total (\%) \\
\hline Sole ulcers & 28 & 19.0 & 118 & 80.3 & 146 & 31.6 \\
Digital dermatitis & 17 & 12.1 & 124 & 87.9 & 141 & 30.3 \\
Thin soles & 23 & 41.1 & 33 & 58.9 & 56 & 12 \\
Interdigital dermatitis & 7 & 13.1 & 45 & 86.5 & 52 & 11.2 \\
Interdigital phlegmon & 1 & 5.3 & 16 & 84.2 & 19 & 4.1 \\
Screw claws & 6 & 35.3 & 11 & 64.7 & 17 & 3.7 \\
Toe ulcers & 2 & 12.5 & 14 & 87.5 & 16 & 3.4 \\
Interdigital hyperplasia & 0 & 0.00 & 7 & 100 & 7 & 1.5 \\
Heel erosion & 0 & 0.00 & 7 & 100 & 7 & 1.5 \\
Sole hemorrhage & 2 & 66.7 & 1 & 33.3 & 3 & 0.6 \\
\hline Total & 86 & 19.6 & 376 & 81.4 & 464 & 100 \\
\hline
\end{tabular}

Souza (2002) analyzed a total of 323 cows among 63 dairies (57 semi-intensive and six freestall) in Minas Gerais, Brazil, and observed hoof lesions, in particular, heel erosion (59.8\%), digital dermatitis $(30.3 \%)$ screw claws, $(24.1 \%)$, white line disease (16.4\%), horizontal wall fissure (15.5\%), interdigital dermatitis $(14.6 \%)$, sole hemorrhage $(11.1 \%)$, sole ulcers $(7.1 \%)$, interdigital hyperplasia $(5.9 \%)$, double soles $(4 \%)$, screw claws $(3.4 \%)$, wall hemorrhage $(3.1 \%)$, and toe ulcers $(1.5 \%)$. Analysis of the conditions of the farms under study revealed high humidity levels on floors, which is typical of a semi-intensive system of production, where a great accumulation of organic matter is also observed, promoting the development of infectious lesions such as digital and interdigital dermatitis.
The distribution between infectious and noninfectious lesions in the cows examined was equal, with percentages of $47.1 \%$ and $52.9 \%$, respectively. The most common non-infectious lesions were sole ulcers $(59.8 \%)$, resulting from biomechanical issues and thin soles $(22.8 \%)$, which occur due to abrasive concrete floors typically used in free-stall dairies (BARKER, et al., 2010). The most common infectious lesions were digital dermatitis (64.4\%) and interdigital dermatitis $(23.7 \%)$, which was expected since a great accumulation of organic matter and high humidity levels were detected in the cowsheds of the visited farms. Additionally, Solano et al. (2016) observed a great percentage of cows with digital dermatitis (15\%), among infectious lesions; similarly, we also believe that the type of 
production system, management practices, and deficient hygiene measures of cowsheds are factors related to a high percentage of animals with foot problems.

The distribution of hoof lesions is depicted in Table 1. Only 86 of lesions (19.6\%) were found on the forelimbs; in contrast, 376 lesions were detected on the hindlimbs. Molina et al. (1999) evaluated dairies in the Belo Horizonte region, Brazil, and detected $66.7 \%$ of foot problems on the hindlimbs and $33.3 \%$ on the forelimbs. Furthermore, Silva et al. (2001) conducted an epidemiological study on foot problems in lactating cows in the Orizona municipality, Goiás, Brazil, and observed a greater prevalence of lesions on the hindlimbs $(87.6 \%)$ than on the forelimbs (12.3\%). According to the authors, the high prevalence of lesions on hindlimbs is related to the biomechanics of locomotion in cattle.

Overall, multifactorial causes of lameness were observed in the farms under study, mainly due to external factors such as inadequate management and housing conditions, such as the use of abrasive floor and high humidity levels where cows were maintained, as well as rough and stony paths that cows used on their way to the milking parlor. These factors may contribute to lameness; the abrasive floor together with continuous high humidity levels on the floors of the cowsheds promoted the development of foot problems.

There was a positive correlation between animals with foot problems and the observed poor hygiene conditions of the locomotor system of the cows reported by farmers. In addition, the main cause of early culling of cows was infections on the cow's locomotor system $(\mathrm{P}<0.05)$. These findings raise the question as to which factors can predispose cows to foot problems, and as suggested by Barker et al. (2010), lesions may occur due to deficient hygiene management practices and type of cubicles used in dairies.
Lesions were distributed into two groups according to their cause (infectious and noninfectious) and their location on the limb was also documented. There were differences in the cause of lesions and their location, with a greater number of lesions being observed on the lateral claws of the hindlimbs. Figure 1 shows the highest number of non-infectious lesions on the lateral claw of the left hindlimb (DL - MPE) $(\mathrm{P}<0.05)$. However, it was not possible to obtain significant results on other locations of the hoofs probably due to high data dispersal.

The lateral claws of the hindlimbs and medial claws of the forelimbs, bear the majority of cow's body weight, which helps to explain the results observed. Digital and interdigital dermatitis were the most prevalent infectious lesions observed in this study, commonly present in the coronary band of the hoof and interdigital space, which are locations with higher humidity levels and where organic matter accumulates. According to Greenough and Weaver (2007), diseases on the foot skin, such as interdigital dermatitis, are caused by bacteria, (primarily by Dichelobacter nodosus, and secondary infections caused by Fusobacterium necrophorum) which are commonly found in locations of high stocking densities, with high humidity levels and where dirt accumulates. These conditions cause softening of the hoofs and skin lesions on the digital and interdigital areas, enabling infectious agents to invade the hoofs (BLOWEY, 2011).

There was a positive correlation between LS, number of lesions per limb, and age (Table 3). According to Nicoletti (2004), age and lactation stage of cows greatly affect foot health, since the older the cow, the greater the chance to develop hoof lesions. Bicalho et al. (2009) reported that susceptibility to lameness increases with the cow's age since older animals have less ability to regenerate soft tissues between the corium and digital cushion of hoofs, which is the reason why 10-year-old cows have are four times more likely to develop foot lesions than are 3-year-old cows. 
Figure 1. Distribution of lesions on the hindlimbs of cows examined in this study, according to their specific location and cow's age, and grouped according to their cause (infectious or non-infectious).
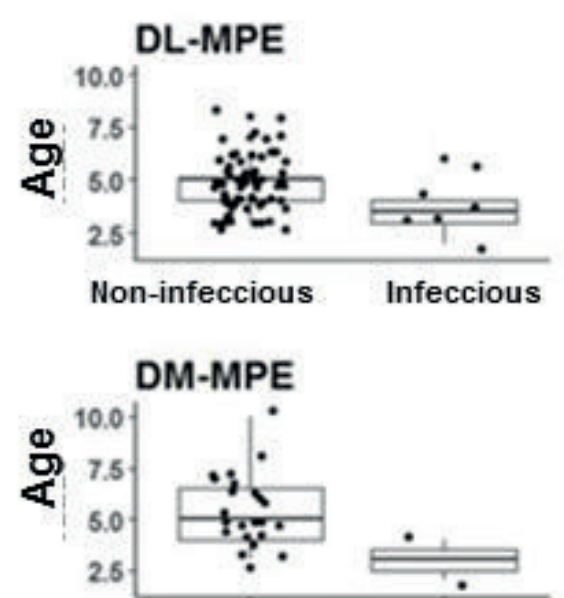

Non-infeccious

Infeccious

ID-MPE

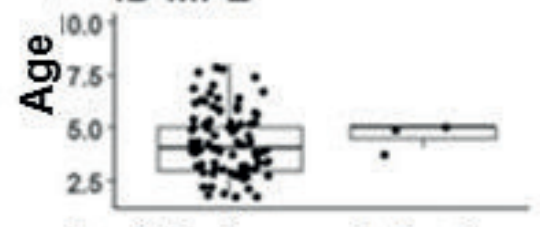

Non-infeccious

Infeccious
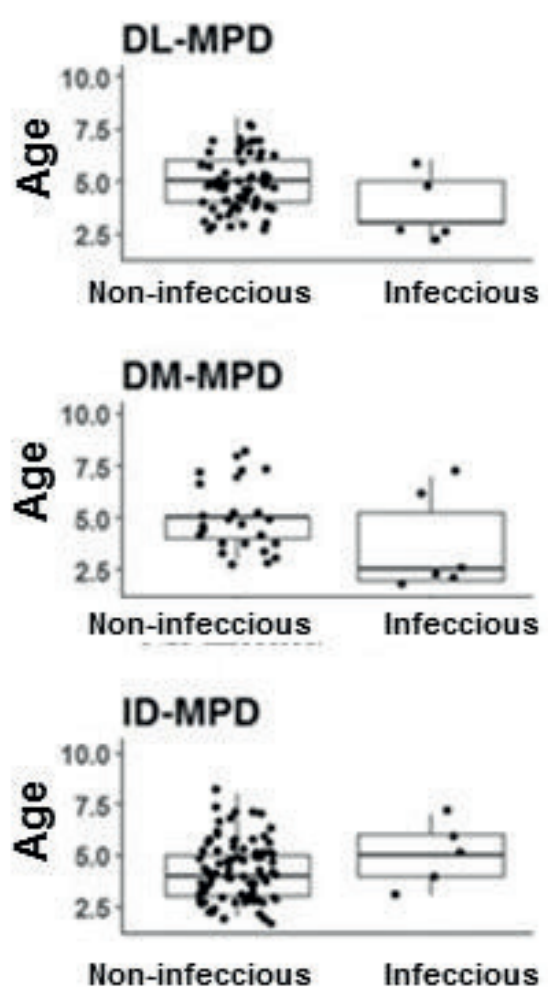

Comparison by t-test. DL: Lateral claw; DM: Medial claw; ID: Interdigital space; MPE: Left hindlimb; MPD: Right hindlimb.

Table 3. Correlation between locomotion scoring (LS), age, and number of lesions.

\begin{tabular}{ccccc}
\hline & LS & Age & FL & HL \\
\hline LS & - & $0.187^{*}$ & $0.205^{*}$ & $0.467^{*}$ \\
Age & $0.187^{*}$ & - & 0.063 & 0.081 \\
MT & $0.205^{*}$ & 0.063 & - & $0.348^{*}$ \\
MP & $0.467^{*}$ & 0.081 & $0.348^{*}$ & - \\
\hline
\end{tabular}

Correlation calculated using Pearson's correlation coefficient; *Significant positive correlation $(\mathrm{p}<0.05)$. LS $=$ locomotion scoring, $\mathrm{FL}=$ Forelimb, $\mathrm{HL}=$ Hindlimb.

According to the answers given by farmers in the questionnaires, among the three main causes of hygiene problems, the locomotor system was the most frequently mentioned. Among the three main causes of early culling, the locomotor system was again the most frequently mentioned. These data show that lameness in free-stall housed dairy cows is an increasing concern especially since the locomotor system used to be described as the third cause of hygiene problems previously. Conversely, when questioning farmers regarding prophylactic measures, such as hoof trimming of cows, we observed a significant difference between the farmers who used hoof trimming as preventive measure and farmers who did not $(\mathrm{P}<0.05)$; herds submitted to hoof trimming presented a lower number of cows with foot lesions, and, consequently, less lameness. Farmers who implemented preventive measures to 
improve dairy cow foot health could control lesions at an initial stage, thus preventing foot lesions from developing into more severe levels of lameness and economic losses.

There was a significant association between implementing preventive hoof trimming and reducing lameness, as reported by farmers, with a rate of possibilities of 0.456 (95\% CI 0.22-0.94); in other words, implementing hoof trimming reduced lameness by $55 \%$. Therefore, preventive hoof trimming is essential as a prophylactic measure for dairy cattle. According to Silva et al. (2001), hoof trimming in addition to with footbathing is recommended once or twice a year for housed cows, with the aim of correcting hoof problems, and to detect foot lesions at an early stage, and thus reduce prevalence of infections and subsequent economic losses.

\section{Conclusions}

The present study demonstrated that free-stall housed dairy cows showed a high prevalence of lameness and foot problems. Preventive hoof trimming implemented frequently in lactating cows reduced lameness risk in the herd. These results should be considered in future research with the aim of teaching farmers and farm technicians on how to improve their management practices and dairy cattle sheds to reduce great economic losses in herds.

\section{Acknowledgments}

We would like to acknowledge the financial support of Capes and the National Council for Scientific and Technological Development (Conselho Nacional de Desenvolvimento Científico e Tecnológico - CNPq).

\section{References}

AMORY, J. R.; KLOOSTERMAN, P.; BARKER, Z. E.; WRIGHT, J. L.; BLOWEY, R. W.; GREEN, L. E. Risk factors for reduced locomotion in dairy cattle on nineteen farms in the Netherlands. Journal of Dairy Science, Vancouver, v. 89, n. 5, p. 1509-1515, 2006.

BARKER, Z. E.; LEACH, K. A.; WHAY, H. R.; BELL, N. J.; MAIN, D. Assessment of lameness prevalence and associated risk factors in dairy herds in England and Wales. Journal of Dairy Science, Vancouver, v. 93, n. 3, p. 932-941, 2010.

BLOWEY, W. R. Color atlas of disease and disorders of cattle. $3^{\text {th }}$ ed. Gloucester, UK, Copyright: Mosby ltd. 2011. $280 \mathrm{p}$.

BICALHO, R. C.; MACHADO, V. S.; CAIXETA, L. S. Lameness in dairy cattle: a debilitating disease or a disease of debilitated cattle? A cross-sectional study of lameness prevalence and thickness of the digital cushion. Journal of Dairy Science, Vancouver, v. 92, n. 7, p. 31753184, 2009.

BRAMLEY, E.; COSTA, N. D.; FULKERSON, W. J.; LEAN, I. J. Associations between body condition, rumen fill, diarrhea and lameness and ruminal acidosis in Australian dairy herds. New Zealand Veterinary Journal, Murdoch, v. 61, n. 6, p. 323-329, 2013.

BORGES, J. R. J.; CÂMARA, A. C. L.; MOSCARDINI, A. R. C.; RODRIGUES, C. A.; PITOMBO, C. A.; GRAÇA, F. A. S.; SILVA, L. A. F.; SILVA, P. C. A. R.; CUNHA, P. H. J.; VIANNA, R. B.; RABELO, R. E.; OLLHOFF, R. D. Doenças dos dígitos dos bovinos: nomenclatura padronizada para o Brasil. Revista Conselho Federal de Medicina Veterinária (CFMV), Brasília, v. 3-5, n. 73, p. 45-52, 2017.

CHAPINAL, N.; BARRIENTOS, A. K.; VON KEYSERLINGK, M. A. G.; GALO, E.; WEARY, D. M. Herd-level risk factors for lameness in freestall farms in the northeastern United States and California. Journal of Dairy Science, Vancouver, v. 96, n. 1, p. 318-328, 2013.

COSTA, J. H. C.; BRUNETT, T. A.; VONKEYSERLINGK, M. A. G.; HÖTZEL, M. J. Prevalence of lameness and leg lesions of lactating dairy cows housed in southern Brazil: effects of housing systems. Journal of Dairy Science, Vancouver, v. 101, n. 3, p. 1-11, 2017.

CRUZ, C. E. F.; PESCADOR, C.; NAKAJIMA, Y.; DRIEMEIER, D. Immuno-pathological investigations on bovine digital epidermitis. Veterinary Record, Porto Alegre, v. 157, n. 26, p. 834-840, 2005.

DIPPEL, S.; DOLEZAL, M.; BRENNINKMEYER, C.; BRINKMANN, J.; MARCH, S.; KNIERIM, U.; WINCKLER, C. Risk factors for lameness in freestallhoused dairy cows across two breeds, farming systems, and countries. Journal of Dairy Science, Vancouver, v. 92, n. 11, p. 5476-5486, 2009. 
DIRKSEN, G.; GRÜNDER, H.-D.; STÖBER, M. Rosemberger, exame clínico dos bovinos. 3. ed. Rio de Janeiro: Guanabara Koogan, 1993. 419 p.

EDMONDSON, A. J.; LEAN, I. J.; WEAVER, C. O.; FARVER, T.; WEBSTER, G. A body condition scoring chart for Holstein dairy cows. Journal of Dairy Science, Vancouver, v. 72, n. 1, p. 68-78, 1989.

GREEN, L. E.; HUXLEY, J. N.; BANKS, C.; GREEN, M. J. Temporal associations between low body condition, lameness and milk yield in a UK dairy herd. Preventive Veterinary Medicine, Coventry, v. 113, n. 113, p. 63-71, 2014.

GREENOUGH, P. R.; WEAVER, A. D. Lameness in cattle. $3^{\text {th }}$ ed. Philadelphia: Saunders, 336 p. 2007.

HUXLEY, J. N. Lameness in cattle: an ongoing concern. Veterinary Journal, United Kington, v. 193, n. 3, p. 610 $-611,2012$.

LEAN, I. J.; WESTWOOD, C. T.; GOLDER, H. M.; VERMUNT, J. J. Impact of nutrition on lameness and claw health in cattle. Livestock Science, New South Wales, v. 156, n. 3, p. 71-87, 2013.

MARTINS, C. F. Prevalência e classificação das afecções podais em vacas lactantes na bacia leiteira de Campo Grande (capital) e municípios arredores-MS. Ensaios e Ciência, Campo Grande, v. 6, n. 2, p. 113-137, 2002.

MOLINA, L. R.; CARVALHO, A. U.; FACURY FILHO, E. J.; FERREIRA, P. M.; FERREIRA, V. C. P. Prevalência e classificação das afecções podais em vacas lactantes na bacia leiteira de Belo Horizonte. Arquivo Brasileiro de Medicina Veterinária e Zootecnia, Belo Horizonte, v. 51, n. 2, p. 149-152, 1999.

MONTEIRO, T. F.; NICOLINO, R. R.; ANDRADE, L. S.; FACURY FILHO, E. J.; CARVALHO, A. U. de. Prevalence of lameness and hoof lesions in all yearround grazing cattle in Brazil. Tropical Animal Health and Production, Edinburgh, v. 50, n.5, p. 1-6, maio 2018.
NICOLETTI, J. L. M. Manual de podologia bovina. São Paulo: Manole, 2004. 126 p.

R CORE TEAM - R: a language and environment for statistical computing. Copyright (C) R Foundation for Statistical Computing. Vienna, Austria. 2013. Available at: <http://www.R-project.org/>. Accessed at: 19/11/2018.

SILVA, L. A. F.; SILVA, L. M.; ROMANI, A. F.; RABELO, R. E.; FIORAVANTI, M. C. S.; SOUZA, T. M.; SILVA, C. A. Características clínicas e epidemiológicas das enfermidades podais em vacas lactantes do município de Orizona - GO. Ciência Animal Brasileira, Goiânia, v. 2, n. 2, p. 119-126, 2001.

SOLANO, L.; BARKEMA, H.W.; MASON, S. Prevalence and distribution of foot lesions cattle in Alberta, Canadá. Journal of Dairy Science, Vancouver, v. 99, p. 6828-6841, 2016.

SOMERS, J. G. C. J.; SCHOUTEN, W. G. P.; FRANKENA, K. Development of claw traits and claw lesions in dairy cows kept on different floor systems. Journal of Dairy Science, Vancouver, v. 88, n. 1, p. 110$119,2005$.

SOUZA, R. C. Perfil epidemiológico e clínico das afecções podais em vacas nas bacias leiteiras de Belo Horizonte e Pedro Leopoldo. 2002. Dissertação (Mestrado em Medicina Veterinária) - Universidade Federal de Minas Gerais, Minas Gerais.

TELEZHENKO, E.; BERGSTEN, C. Influence of floor type on the locomotion of dairy cows. Applied Animal Behaviour Science, Skara, v. 93. n. 3-4. p. 183-197, 2005.

VON KEYSERLINGK, M. A. G.; BARRIENTOS, A.; ITO, K.; GALO, E.; WEARY, D. M. Benchmarking cow comfort on North American freestall dairies: lameness, leg injuries, lying time, facility design, and management for high-producing Holstein dairy cows. Journal of Dairy Science, Vancouver, v. 95, n. 12, p. 7399-7408, 2012. 
